\title{
, \\ Muslim Women in Interfaith Partnerships in Germany
}

\author{
Mona Feise-Nasr (iD
}

check for

updates

Citation: Feise-Nasr, Mona. 2022.

Muslim Women in Interfaith

Partnerships in Germany. Religions

13: 193. https://doi.org/10.3390/rel 13030193

Academic Editor: Amina Jamal

Received: 31 December 2021

Accepted: 21 February 2022

Published: 24 February 2022

Publisher's Note: MDPI stays neutral with regard to jurisdictional claims in published maps and institutional affiliations.

Copyright: (C) 2022 by the author. Licensee MDPI, Basel, Switzerland. This article is an open access article distributed under the terms and conditions of the Creative Commons Attribution (CC BY) license (https:// creativecommons.org/licenses/by/ $4.0 /)$.
Berlin Institute for Islamic Theology, Humboldt University of Berlin, 10117 Berlin, Germany; mona.feise@hu-berlin.de; Tel.: +49-30-91442657

\begin{abstract}
The number of Muslim-interfaith couples in European countries has become significant due to transnational migration and a growing number of Muslims living in Muslim Minority countries. While the challenges for partners in such unions are complex, this article focuses on the lived experiences of Muslim women in interfaith intimate relationships in Germa ny. Drawing on field interviews with women in mixed-faith relationships, the following questions are central: How do Muslim women conceptualize religious identity and practices? Do they face challenges from different groups (Muslim communities, their families, friends, etc.) and if so, how do these challenges manifest? If respondents create concepts of being Muslim for themselves, how do these evolve in their narratives? How do they question, adapt or discard theological and social demands? Preliminary results illustrate that some respondents would appreciate a Muslim community that accepts their positionality as intermarried Muslim women. Looking at the narration of religious practices and concepts of Muslimness in the interviews, it becomes clear that a classification as haram, or legally forbidden, puts a simple categorical bar in front of a socially and theologically complex context. The inquiry combines interview analysis with situational mapping and is informed by Grounded Theory methodology.
\end{abstract}

Keywords: women and gender; religious practices; religious heterogeneity; Muslim minorities; interfaith partnerships; Muslims in Germany

\section{Introduction}

Germany, alongside other European countries, has a significant Muslim minority population from diverse backgrounds, with complex identity connections and various religious practices. Mixed-faith partnerships between Muslims and Non-Muslims occur but are still not a common phenomenon in this Muslim-minority context. For Muslim women, there are particular hindrances presented both by a Christian secular majority population and its concepts about Muslims as well as by Muslim communities and peer groups. Most classical and modern Muslim scholars, hold the conviction that marriage (including intimate relationships in general) between Muslim women and non-Muslim men, is forbidden in Islam. Muslim women thus navigate a field of tension that infiltrates both their religious and their intimate agency with legal and social normativities. They are also confronted with opinions about the compatibility or incompatibility of being both (visible) Muslim and European. These narratives are often rife with stereotypes and expectations towards Muslims to represent a 'European' Islam and adapt their (religious) practices and expressions according to this image. Consequently, visible religious practices, like clothing or praying in public spaces, regularly stir controversies and questions about radicalization (e.g., Der Tagesspiegel, 11 August 2019, (Fröhlich et al. 2019)). Regardless of their individual degree of religiosity and to what extent and how they engage in religious practices, visibility - that is, being 'out' as Muslim or being interpreted as Muslim by one's environment-intensifies an individual's involvement. Women, especially their clothing, are regularly employed as yardsticks for Western 'progressiveness' towards imported 'Oriental cultures' in European countries. Social questions that concern all women, such as 
unequal payment, limited career options or harmful body images, fade into the background in these narratives.

This article briefly recaptures the idea that arguments against the relationship between Muslim women and non-Muslim men are often based on a mixture of theological, legal and social assumptions and interpretations of the Islamic authoritative sources Qur'an and Sunna (the prophet Muhammad's way of life and legal precedent). In this manner, the Islamic tradition is recurrently brought forward as a frame of reference in which these theological, legal, and social aspects interact and influence each other.

The significance of this paper is to relate these debates to the lived experiences of Muslim women, situated within the German Muslim-minority context. It will shed some light on how intermarried Muslim women establish personal narratives to maintain coherency for their religious subjectivities and how 'doing-couple' practices shape and are shaped by a multiplicity of identifications and belongings. This includes showing religious agency exercised by questioning and adapting majority positions about intermarriage.

Research studies on Exogamy of Muslim women

Research that focuses on Muslim women who are in interfaith unions with non-Muslim men (e.g., Elmali-Karakaya 2021; Jawad and Elmali-Karakaya 2020; Buisson 2016; Abdelnour 2020) analyses shared and separate religious practices between partners, concepts and 'degrees' of being inter-faith, dominance of one religion over the other or children's religious education. These researchers conclude that being in an interfaith union influences the religious observance in two ways. It either has no effect or has a positive impact on the practice of their religion (Elmali-Karakaya 2021). The main reason for the positive change was Muslim women's feeling 'of being an ambassador of Islam and Muslims in their interfaith families (Elmali-Karakaya 2021, p. 388). Buisson (2016) presents the interpretation of Islamic sources that serve as basis to Islamic tradition to generally accept interfaith marriages for men as lawful (halal) while prohibiting interfaith marriages to Muslim women. The classical scholars of the Sunni branches of Islam promote a non-reciprocal view on interfaith marriages for Muslims. The consensus was that the marriage of Muslim men with Jewish or Christian women is lawful but should be banned when it comes to Muslim women. Shiite scholars only regard temporary marriages for Shiite men to non-Muslim women as allowed while permanent marriages are prohibited (Buisson 2016, p. 433). Buisson emphasizes that classical commentators were aware that the Qur'an is silent on the matter of interfaith marriage for Muslim women and that the prohibition is a deduction from this silence, i.e., from a permission not directly given. Exemplarily, she shows that the scholar al-Qurtubi saw the need to explain the prohibition as a consensus (ijma) of the community (Umma). Buisson argues that the Qur'an allows marriage between Muslims and any believer of the people of the Book (Jews and Christians) for both Muslim men and women, if intentions are honest and trustful (p. 445). She substantiates her judgement with verse 5:5 of the Qur'an and follows its non-patriarchal interpretation that is based on the principles of gender equality and reciprocity. This interpretation is favored by some contemporary Muslim exegetes of the Qur'an with a gender justice perspective (e.g., Amina Wadud 1999; Asma Barlas 2002; Kecia Ali 2006; Asma Lamrabet 2016).

Jawad and Elmali-Karakaya (2020) conducted interviews with Muslim intermarried women from Turkish origin in Britain. Their paper discusses the Islamic view on women's interfaith marriages, assesses the impact on the women, and challenges they face theologically and socially including strategies they develop to deal with their situation. Controversies become apparent, when comparing Buisson's and Jawad/Elmali-Karakaya's conclusions. The latter call for Islamic theologians and Muslim communities to address the question of exogamy among Muslim women in order to make them aware that such a marriage is not 'just' societally unacceptable but, a conviction shared by the authors, that Islam prohibits interfaith marriage to Muslim women ("The present study also reveals that some Turkish women do not know that a Muslim woman's marriage to a non-Muslim husband is prohibited in Islam", (Jawad and Elmali-Karakaya 2020, p. 18)). Buisson quite the opposite, advocates for the right of exogamic marriages for Muslim women based 
on a reevaluation/re-observation of the indirect Qur'anic prohibition and points at the establishment of gender sensible readings of the Qur'an. In a similar direction goes the account of Abdelnour (2020) who investigates the contributions of al-Ghazali (d. 1111), Ibn Taimiyya (d. 1328), and presents the view of Muhammad Abduh (d. 1905) and Abd Allah al-Alayli (d. 1996) regarding exogamy.

The example of the British context

The following outlook on Great Britain regarding the subject of exogamy of Muslim women presents a European setting that has similarities with the German conditions. Yet, the topic of intermarriage seems to be more publicly present than in Germany (e.g. 'Halal' Interfaith Unions Rise Among UK Women 2012. Aljazeera, December 31).

In 2012, the London Christian-Muslim Forum, in collaboration with the Interfaith Marriage Network in the UK, published a guidebook for chaplains, imams and other religious leaders (Interfaith Marriage Network 2012; available in: (When Two Faiths Meet-Marriage, Family and Pastoral Care: Ethical Principles 2015)). It responded to a need of religious authorities for practical advice on dealing with the pastoral concerns of interfaith couples. It also considers controversial topics such as exogamic marriage of Muslim women, as Muslim imams and Christian ministers have recognized a rise in marriages between Muslim women and non-Muslim men in Great Britain. After consulting with hundreds of couples, the initiators listed a series of guidelines calling for a more flexible approach to interfaith marriage. Shaykh Ibrahim Mogra is one of them. While he does not endorse interreligious marriages in general, he emphasizes the need to provide theological service for those who feel "miserable about their choice" and opposes cajoling spouses to convert to Islam (Mogra, Al Jazeera 2012). The only British imam who publicly disagrees with the differences made between Muslim men and women regarding interreligious marriages is Taj Hargey from the Muslim Educational Centre of Oxford. He states that "there is no verse in the Holy Qur'an that bans Muslim women from marrying non-Muslim men". (Taj Hargey, Al Jazeera, 2012). He is one of very few imams in Europe who conduct Islamic marriages between Muslim women and non-Muslim men.

Theoretical Analysis of Religious Practices

This paper conceptualizes religious practices as social practices and follows definitions from practice theory of 'practices' and 'practical meaning'. Important here is that all practice is constitutively connected to sense and meaning that are shaped by culture and as such become discernible in practices. As Akca, Abuali and Süer discuss in their forthcoming chapter on a practice theory approach to Islam, the inclusion of embodiment and material religion in the study of Islam and the practices of Muslims allows us to reexamine the normative and its constitution (Akca et al. Forthcoming). The practical sense forms in the performance and makes the enactment detectable, e.g., through symbols and cultural forms (Hillebrandt 2014). Meaning is comprehended as a by-product of the practices that are taking place; it does not arise accidentally. In the association between socialized bodies and artifacts, practices are constitutively connected with practical meaning, since the "socially shaped body" (Bourdieu 1976) is not conceivable without meaning. The interconnection of norms and practices can be elucidated by studying practices that comprise behaviors, emotions, doings and sayings as well as artefacts (Akca et al. Forthcoming). The interview paragraphs presented in this paper, reflect the interdependence between norms and practices in narrative accounts of negotiation processes. The conditions for the emergence of practical forms are understood dynamically, i.e., it is not regarded as an apparatus that always reproduces itself in the same way. Practical meaning is thus more than "the ABC" (attitudes, behavior and choices) of individuals (Shove 2010).

\section{Material and Methods}

The data presented in this research was taken from five in-depth Muslim-interfaith couple interviews and two single interviews with Muslim women living in interfaith partnerships in Germany between December 2019 and July 2021. They are part of a sample 
consisting of sixteen partner- and five single interviews conducted for an ongoing doctoral thesis with the working title "Muslim-interfaith couples and families in Germany". For the doctoral research, the interview sample is complemented by field memos and family ethnography as interviews commonly took place at couple's homes. The seven interviews have been chosen for this paper due to the couples' constellation with the female partner identifying as Muslim. With that, analyzing their accounts allow for exploration of the research field which is a purpose of sampling in qualitative research (Flick et al. [2005] 2017, p. 167) with the purpose of conceptual representativeness (Strübig 2008, p. 32). The selected paragraphs were translated from German into English. All participants are either part of a Muslim-Christian or a Muslim-Questioning/Agnostic couple. The female interviewees presented in this paper all have a middle-class background, in most cases an academic education and live in the metropolitan area or in municipalities near a larger city. They are all financially independent, be it employed or freelance.

The biographical-narrative interviews motivate the interviewee (s) to give a detailed narrative of a phase of their life (Menz 2008). One needs to consider that in couple interviews in addition to the individual account of each respondent, certain relationship narratives are introduced to the interviewer. Couples were given leeway to put the focus on topics relevant to them while follow-up questions posed by the researchers served to balance accounts and to inquire details. Guiding questions were about partnership's history, family of origin and childhood, housing situation, the role of religion in the partners' upbringing, religious practices and festivities, (religious) education of children, self-definition of being an interfaith/interreligious/interracial couple, social network and community life. The interviews confirm that couple-biography narration often profits from mutual stimulation of pairs (Przyborski and Wohlrab-Sahr 2014, p. 109). With that, it is noteworthy that in the couple interviews power dynamics and negotiation processes were often both articulated more subtly while being brought up recurrently made them more conspicuous than in individual interviews. While in the latter, accounts dwelled longer on biographical details, in couple interviews doing partnership, negotiations about different ideas of heterodox or orthodox religious practices, spiritual mindset and outlook at life realities were articulated more prominently.

The analytical approach to the interview material stems from discursive analysis in combination with a practice theoretical approach which puts bodily practices, materiality and performance in the forefront of the analysis (Reckwitz 2002, 2003). Situational Analysis (Clarke 2005; Clarke et al. 2015) as a methodology rooted in Grounded Theory is employed to get hold of the social dimensions intertwined with the narratives that are presented through the interviews. Situational maps, one of the tools of SA serve to carve out the narrative interconnectedness in the fabric of partnership and religious and cultural practices for analysis. As a matter of data security, pseudonyms are used for all respondents.

The software MaxQDA is applied for the analysis of interview transcripts and field notes. Through several processes of coding (Strauss [1987] 2003) categories are developed. Codes developed in the open coding process during the analysis of the interview material presented in this paper are concepts of spirituality, concepts of religious norms, personal belief, religious practices in shared spaces and negotiation practices. The systematic narrowing shall serve differentiation and subject development (Strauss and Corbin [1996] 1998, p. 136). A later step in the ongoing research is selective coding, a procedure for building a story that connects categories to produce a discursive set of theoretical assumptions. Core categories are developed that become concepts or analytical tools with which the research object is approached. The purpose of these categories is to make them transferable to other data that is gathered in studies on interfaith intimate partnerships and marriages.

\section{Case Studies/Results}

The following case studies are structured according to aspects that came up repeatedly in different forms during the interviews and seemed to be of major significance to the respondents. As mentioned above, the central research questions revolve around concepts 
of religious identity and practice, potential challenges respondents meet from different groups, narrative concepts of being Muslim and the response to theological and social demands.

\subsection{Spirituality and Religion}

I argue that 'spirituality' is employed by the respondents as a mediating concept to emancipate from established norms. It sets new norms for values to meet needs and to answer questions that had arisen during a formative period of their life. It is therefore not an arbitrary way to struggle free from inconvenient normative standards, but a product of an inner reflective process that engages with concepts of belief to attain or retain practical meaning. In the Muslim minority context of Germany, the Christian-secular frame and its epistemological power needs to be taken into consideration when analyzing concepts of spirituality.

The respondent Enisa says that she had spiritual experiences at different stages throughout her life. Her father taught her about Islamic mysticism when she grew up. She emphasizes that she experiences God in everyday life and speaks about her belief in the existence of God in terms of "spirituality" or "the spiritual" which she sees more fit to reflect her mindset than "religion" or "belief".

Enisa: “[...] I am praying for small things, so I pray in my head [...] I also pray for a parking lot [...] So religion, or rather spirituality, is important for me. Um, that is always somehow in me, God. Like, every day." (Interview Enisa and Silvia)

Enisa employs a personal narrative to relate to God, with very concrete examples rooted in daily routines and experiences. This is relevant when thinking about the epistemological weight of the term 'religious' and what counts as religious practices. Some practices are normative and marked as religious, such as the Islamic ritual prayer (ar. salāh, tur. namaz) or the preceding ablution (arab. wuḍ $\left.\bar{u}^{\prime}\right)$. Other social practices cannot easily be categorized as 'religious'. When Mariam, another respondent, is asked what it means to her to be religious, she mentions the topics of sustainability, climate and precarious working conditions.

Mariam: "During shopping for example, when I think 'Is this sustainable?', 'Is this climate friendly?', 'Are people being exploited to make this product?'” (Interview Mariam and Sebastian)

While Mariam performs religious normative practices like the daily prayer infrequently, other social practices, such as calling sick relatives, are integral to her religious self-image.

Mariam: “Well, I don't pray five times a day, or at least not regularly. [...]

Fostering social relations, calling or visiting when someone is ill. These matters are present in my life through my belief."

It becomes apparent, that several respondents understand 'the spiritual' and spirituality as a connection to a source of inner coherence and sense-making that they had acquired during their upbringing. A concept of spirituality enables them to safeguard this source while it also permits them to criticize the 'system' within which this source was originally constructed. The system is the religious education they received during a formative period in their life. Spirituality serves as a space to connect a known territory with new needs and sensitivities that arise during another period in one's life and can't be answered or accommodated by the structures the known territory consists of. Spaces are (re)produced through routines of recursively reproduced structures. According to this model, however, changes that are made possible when deviations or new creations become regular, do not remain individual, but become collective, drawing on relevant rules and resources (Löw 2001). Thus, changes of institutionalized spaces up to structural changes can take place. Impulses for deviations or new creations can be factors such as "insight into necessities", "bodily desire", "negotiation processes" or "strangeness" (Löw 2001, p. 184). 
Miral describes spirituality as an approach to belief and religious values that enables her to overcome feelings of guilt as she is not able to abide by all Islamic norms she grew up with.

Miral: "[...] I decided not to engage with religion anymore for now but to approach the matter more through spirituality/what I am sure about is, that I believe in God and the Divine. I departed from rules, that I should abide by [...] I always felt guilty about that. [...] And we had talked a lot about that. And it started to be about the spiritual." (Interview Miral and Jonah)

Miral felt alienated from the religious norms she has been raised with while they were still relevant for her, causing remorse for not to being able or willing to abide by these norms. She realized the necessity to find an approach to religion that creates a sense of congruency with her positionality as a young educated Muslim woman in a Muslim minority context who shares in social practices like the consumption of alcohol or premarital sex. Acts that were deemed 'forbidden' by the religious norms she had been convinced were fundamental for her Muslim identity. In practice theoretical terms, sense and meaning were re-shaped by the adaption of new practices while the practices themselves generated new practical meanings as byproducts of these processes.

Hayat, a German Muslim convert, also has "a journey with circuitous routes" to Islam behind her, leading from an interest in Buddhism back to Catholicism and through Universal Sufism to Islam.

Hayat: "I don't feel the need to leave the [Catholic] church even though I don't feel attached to Christianity that closely. For example, for me, Jesus is not the son of God, I regard him as a prophet [...] Someone at Facebook once called me a Sufi -like freestyle Muslima. And I think this description suits me." (Interview Hayat)

It seems astonishing that Hayat, presenting herself as Muslim, is on paper a member of the Catholic Church while disagreeing with one of the core concepts of Christianity, namely considering Jesus to be the son of God. Her example notably shows discrepancies between formal membership and religious beliefs and practices that tend to stay invisible when not explicitly mentioned by the person they concern. It can also be interpreted as an illustration of a religious search that manifests in biographical artefacts which resist congruency of someone's religious identity.

Thinking about the meaning of "identity", making sense of one's world is one of the core functions of this concept. Enisa mentions the afterlife linked with the expectation that there must be something "afterwards" that answers questions she has. She asks herself what the sense behind it, existence, could be. According to the Islamic creed, all good and bad come from God, which includes suffering as well.

Enisa: "But I still have such a need for answers. In the end, it's probably just one answer. But I can't imagine it any other way, existence. [...] What is the meaning of violence? [...] And it is said that in Islam, God created everything, both the good and the bad." (Interview Enisa and Silvia)

Her considerations illustrate how a religious precept guides a person's cognizance when facing existential questions which may or may not result in religious practices such as praying or fasting. It can be argued that the cultivation of religious cognition, so to speak, is not necessarily spatiotemporally linked to practices, meaning that practices can follow the mindset with a delay, e.g., in a special stage of life such as aging or triggered by strokes of fate.

For Enisa and her partner it is important to not only cultivate a shared ground on religious ethics in daily life with each other but also to point out differences in their belief to their daughter. This concerns the concept of Trinity as well as the differences in creed when it comes to Jesus as prophet or son of God.

Silvia: "Well, yes, Jesus is for me more than just a messenger, but there is more and (..)" 
Enisa: "Let's change the topic [smiles]."

Silvia: "[...] Well we have a different approach here. And we try to make this clear to Emine [daughter]: I believe this and Enisa believes that."

Differences in religious creeds between partners were rarely foregrounded in the interviews conducted for this research. Interviewees frequently emphasized that differences are not relevant in day-to-day life. They were mostly mentioned in relation to religious festivities, norms or-like in Silvias's and Enisa's case- - when the religious education of their offspring came up. For them is important to keep their faiths distinct from each other and to make their daughter aware of differences in religious dogma and practices for instance when celebrating Christmas and Ramadan as a family.

Mahnoush, a Shiite Muslima, recalls that life experiences and religious education changed her perspective at religion so that she almost completely shifted away from her religious beliefs. At present, it is essential to her to pray at least once per day and to be thankful. She underlines that even though her fiancé does not pray, neither the Islamic nor the Christian prayer, he is thankful towards God, which she regards most important. For Mahnoush, the act of the bodily prayer is formal and the physical practice incorporates the gratefulness. Furthermore, she also makes clear that while being a practicing Muslima who is wearing the hijab, this is just one element of her identity which does not completely constitute her, despite prevailing social assumptions.

Mahnoush: "I always want to free myself from that and would like to say 'I am not what you think'." (Interview Mahnoush and Ramón)

Mahnoush explains that she is wary on how people might interpret her as a visible Muslim due to her hijab and points out that she does not like to be categorized solely according to her religion. She describes religion for her to be a way of living without the necessity to permanently referring to it. She welcomes that in her neighborhood the percentage of visible Muslims is relatively high, with an infrastructure that caters to them, which results in a high availability of halal products. The visibility also makes women who, like her wear the hijab, feel less alien. She describes the relationship with her fiancé Ramón as a connection on a spiritual level which overcomes cultural and linguistic differences. This is a parallel to Miral who also emphasizes 'the spiritual' to be a common base and mindset with her non-Muslim partner. In general, religion as a term is more present in the interview with Mahnoush and Ramón than in the interviews with Enisa, Miral and Mariam.

This example shows that some practices have a greater penetrative power in discourses than others, because they hinge on stereotypical and/or fear-inducing images. Wearing a headscarf or a certain style of beard, is an example of such practice in a Muslim minority context like Germany in the 21st century. Mahnoush's example also hints to the false a priori assumptions that religious affiliation is context independent and the main determinant of (Shiite) Muslim women's actions or their primary form of identification and belonging.

When referring to their shared beliefs and practices, including among others praying, ablution and sharing meals, both her and her fiancé describe them as Islamic. Mahnoush explains that they both have 'the same' religion without being able to attach a name to it. It is neither Christianity nor Islam nor something in between the two. She does not employ the term 'spirituality' to circumvent normative differences between Christianity and Islam.

Mahnoush: "[...]. And any definition and any attempt to describe it, [is] not what it genuinely is. I think we both have the same religion, but I would not call it Islam, Christianity, or anything in between. It's just what it is."

To regard oneself as a practicing Muslim does not necessarily mean to abide by normative concepts of religious practices. Praying as a religious practice is central to most of the Muslim female participants while practices of praying differ between them and are not necessarily to be equated with the ritual Muslim prayer (ar. salah, tur. namaz). For Selma, it signifies to converse with God about personal matters and to find consolation. She experiences the impact that praying has on her life. Islam expressed in one sentence for her is" Be a good person." This maxim functions not only as a religious but also as a 
social core value to build her relationship with her husband on. Wearing a hijab is in her eyes an obligation that she did choose not to follow, and she mitigates the graveness of this decision by referring to God as merciful and forgiving.

Selma: "Of course, there is no human being who is without a sin. Yes, hm, for example, that I don't wear a headscarf or other things. Everyone, consciously or unconsciously, sins somehow. But God is merciful and forgiving." (Interview Selma and Konstantin)

She also points out that asking questions about religious aspects signifies that a person is interested in learning about the belief. On the other hand, the human's capacity to understand is limited and not understanding an explanation does not mean that there is none.

For Nazira, also a Shiite Muslima, belief is strongly connected with charity work and supporting marginalized people in need. Through this religious activism, she also had met her future husband, a Protestant priest. As a minister's wife, she played an important role in most community activities within the parish until her husband's retirement and was also confronted with a lot of power struggles within the church council. Singing in a church choir and conversations with her husband helped her to preserve her belief. Sufi music played an essential role for her connection to Islam and Nazira does not differentiate between religion, spirituality, and belief when talking about the influence of Sufi music on her relation to religion. A central purpose is for her to make sense of the surrounding world while she withdrew from the normative concepts of practicing religion she had grown up with.

Nazira: "[...] that I find answers in religion on what constitutes the human being and the society. I never became a member of a party or turned to any ideology, because in my opinion, everything is said with religion. [...] I have a yardstick [in religion] of mercy which has always guided me. [...] I don't practice the ritual prayers and fasting. Or I practice them in my way."

The esthetical elements of music, dancing, and the bodily involvement in rhythmic movements, is also prevalent in Hayat's account of what got her interested in Islam, especially in Islamic mysticism.

Hayat: "I felt the presence of God in the hadra [arab. presence] [...] before I even knew the meaning of this word."

The hadra is a collective ritual that is performed in Sufi orders and includes a variety of dhikrs (remembrance), recitation of the Qur'an and other devotional texts as well as religious poetic chanting. In the Burhaniyya Sufi circle Hayat visits regularly, men are very expressive during the hadra while women pray silently. Burhaniyya women used to dance, too and were physically involved in the event but Shaykh Sayyedi Mohamed, the current leader of the Burhaniyya Sufi order, restricted this practice and ordered women should pray in silence. Hayat emphasizes, that apart from during the hadra and the prayer during which the women pray behind the men, there is no gender segregation.

Hayat: "This [separation during prayer and hadra] does not bother me at all [...]. I don't like to pray in front of men. [...] the women have a nice room that is separated by a folding screen from the room the men use during hadra. [...] After the hadra, the folding screen is removed, and the men serve the women tea. [...] But I don't want [permanent separation], I think it's not in keeping with the times."

The respondent defines which degree of gender separation is acceptable to her according to social norms that are not directly mentioned in the paragraph. Several aspects become apparent in her assessment: the importance of adequate space (a "nice room"), the positionality of bodies and physical contentment ("I don't like to pray in front of men") and social gendered practices ("[...] and the men serve the women tea"). Religious practices 
take place in spaces that can be interpreted as religious (such as mosques) but that also contain other social practices that structure this space.

\subsection{Challenges by Social Expectations and Authoritative Narratives}

Miral's mother, who is a Muslim with a German-Egyptian background, met a German non-Muslim man after the divorce from Miral's father. During a visit to Egypt, her partner converted to Islam, which made it easier for the family to accept him. Before that, their relationship had caused some conflict with Miral's sisters.

Miral: “[...] especially for my sisters, it's not okay to marry someone who isn't/so a Christian woman can marry a Muslim, but a Christian [man]can't marry a Muslim woman. Um, my mother sees it a little differently, but still her partner had converted."

When Miral herself announced her relationship with a non-Muslim to her family, her mother was rather supportive, while her sisters openly opposed her choice. After more than one year and a half into the relationship, Miral decided to also let her father in on it.

Miral: "I didn't want to discuss this [the relationship] with him at first. Our relation isn't awesome to begin with, and we often have differing opinions [...] he was then more relaxed about it than I had feared."

The example of Miral's family shows that there are differing practices on strengthening or challenging a normative discourse not only in between generations but also within the same generation. Subsequent generations might follow practices that either question and adapt norms or that underline their legitimacy. Not only does a multiplicity of normative discourses exist in written texts, like in 'ulama (Islamic scholars) legal treatises or in material artefacts but also in networks of practices which themselves are situated in frameworks of sociality.

Miral describes that in her family, engagement is regarded as the sole legitimate frame to get to know each other better before marriage. This engagement phase usually takes between several months and two years, as seen in the case of one of her sisters. In delaying the meeting between her boyfriend and her parents, she adapted the norm while not completely disregarding it.

Miral: "We were discussing this. I explained to Jonah that if I told my father [about us], not much time should go by until we get engaged."

For Mahnoush it was also a challenge to balance her life with her partner Ramón in Germany and to conceal the nature of their relationship when they both visited her family in her home country for the first time. It became clear to her parents that Ramón had an interest in Mahnoush, though this fact was framed as an interest in marriage.

Mahnoush: "They knew you [Ramón] were interested in me, which meant for them that you would like to marry me [laughs]. [...] My mum, she didn't even accept him coming to our house once for dinner. [...] But meanwhile we had a different life here [in Germany]".

Her situatedness as an educated woman with a middle-class background also facilitated the access to certain financial and social resources that enabled her geographical independence. As a result, Mahnoush could establish this "different life" in which her agency was not limited by social norms that she did not agree with.

Mariam likewise had to navigate her parents' reservations and rejection of a nonMuslim partner. As in Miral's case, negotiations about the terms of introducing her partner to her family were a prerequisite to take part in social practices expected of her and adapting these to the couple's situation.

Mariam: "And I confronted [him] quite quickly with the fact that I just want to open up about us towards my parents, after we will have agreed on entering into a serious relationship." 
She describes that her parents, who are living in Turkey, were very concerned after she broke the news to them. They went to see two or three Hodjas (turk. title for Islamic scholar or wise person who advises on legal matters) to ask whether an interreligious marriage represents a violation of Islamic norms. Mariam is not sure about the origin of the legal opinion-hold by a majority of historical and contemporary Islamic scholars-that such a marriage is haram (legally forbidden). In the interview, she refers to the opinion as "rule", "hearsay" and " rumor". Rather than interpreting this as a lack of knowledge about the theological rationale, one can argue that her "lack" of normative knowledge represents a conscious decision to bypass this discussion. Two of the hodjas asked for advice by Mariam's parents contradicted each other: one considered the marriage between a Muslim woman and a non-Muslim man forbidden under Islamic law, while the other hodja considered such a union possible. In the end, her parents left it up to Mariam to decide whether she could justify such a marriage before God.

When Selma met her future husband, he was a Catholic and "culturally Christian" but did not follow any kind of religious practices. Selma knew that her parents, who raised her and her brothers and sisters as Muslims, would find it hard to accept that she sees someone from a different faith. Talking about religion, especially about Islam, was essential at the beginning of their relationship.

Selma: "And then we compared and so on, and then the question came up, Muslim, non-Muslim, is that possible at all? So, we engaged with the topic, and you [her partner]discovered it [Islam] for yourself and converted."

Selma emphasizes that she and her partner had reached the conclusion that what matters would be that he does not hinder her to practice Islam, regardless of him being a Muslim or not. Her husband's conversion was therefore not regarded by either of them to be a prerequisite for marriage. It nevertheless smoothened things with Selma's parents and made it easier for them to accept her daughter's choice.

Selma: “And my mother was worried. A German! How can this work out? But my father said, well, if he is a Muslim, if he is a good person. [...] For my father, it was sufficient to know that you [her partner] are a Muslim."

Exogamic marriage can also mean for Muslim women to be implicitly or explicitly excluded from religious communion and solidarity. Nazira felt not accepted in the Muslim (Sufi) communities she visited as a Shi'ite woman who is married to a Christian. For example, she made the experience in a Naqshbandi Community, that the Shaykh did not question her interreligious marriage while the members of the all-female zikr circle she visited, criticized her heavily. They refused to believe that their Shaykh had left the issue unchallenged. When Nazira confronted the Shaykh with the different stances towards interreligious marriages, he admitted that the community is stricter than he is on some issues.

Nazira: "Even though they are outwardly always liberal, they were very traditional [...] I didn't find my place there as a woman [...] and with my background."

Hayat 'flirted' with Islam without considering converting at first due to concerns about gender roles and assumptions about attitudes towards women that she would not want to be ascribed to. Interestingly, she did not mention whether she similarly reflected on the position of women when she got involved with the multi-faceted field of Buddhism.

Hayat: "I didn't think about conversion also because I thought 'I don't want this as a woman.' So I observed it [Islam] for ten years and [...] I had strong reservations".

As mentioned above, Hayat started to attend meetings of a Burhaniyya Sufi circle in Germany and felt especially attracted to the Sufi ways of praying and zikr circles. She was surprised by the gender dynamics between men and women and that most women just wore a headscarf for prayer, loosely over the head. Hayat describes how she eventually converted at a woman's home with the latter being the only witness. 
Hayat: "I visited her for coffee and hadn't something in mind like that [conversion]. I just felt right at that moment. [...] That was ten years ago [...] Just with one other 'sister', so not completely according to the rules because [you need] several witnesses. It just happened."

Hayat's example allows us to trace the positionality of a Central European Muslim convert who, without a history of migration, shares in majority discourses. She also partially steps out of it through the practice of conversion and acquires a share in the minority context. Situatedness is not a static positioning but must be understood as a processual and changing concept. Hayat's journey to Islam was marked by this situatedness and her religious practices developed through it.

Nazira describes a Muslimness that is (made) invisible not only by a missing consistency in religious practices that are read as being "Islamic" by one's surroundings, but also by the lack of acceptance from Muslim communities she experienced. Nazira recalls that at numerous occasions of interreligious dialogue she organized for her husband's parish, members of Muslim communities challenged her whether Christians are believers or if they are kafirun (unbelievers). These episodes reflect a widespread attitude that Muslim women who are married to or in partnerships with non-Muslims, are often confronted with either by community or family members-regardless of the questionable theological value of these statements.

Nazira: "You are not regarded as a [proper] Muslim to the Mosque communities. [...] For them [the family] I lived in an illegitimate relationship because I didn't have an Islamic marriage."

Miral recounts that sexuality wasn't broadly discussed in her family. She eventually encountered different interpretations by Muslim researchers on subjects relating to sexuality and gender in Islam during discussions with her cousins, as well as through books, podcasts and other social media re-sources. The respondent was able to access these discourses due to social and educational capital (Bourdieu) she has acquired when growing up. She also witnessed different approaches to practicing religion by her mother and father but was nonetheless convinced that there is a 'proper' way

Miral: "Well, I had always assumed, that there is just one form of Islam which I either follow, then I am a Muslima or [if not] I am considered as nonreligious. And then I tried to find a path of my own [...]."

Over the years, it became rare in Miral's family that all members come together for Id al-Fitr (Feast of Breaking the Fast) at the end of Ramadan and fasting has lost its centrality as a religious family event. Still, Miral would like to preserve Ramadan, at least in part. She got introduced to therapeutic fasting by her partner. She tried it out as a replacement of full fasting and admits, that she is does not feel completely comfortable with this modification. While fasting in Ramadan is mainly regarded as a religious obligation to be fulfilled, contemporary therapeutic or medical fasting in its different forms is applied for personal (health) benefits.

Hayat states that in retrospect, she would prefer to marry a Muslim because belonging to different confessions can produce problems. She recounts that Ramadan regularly causes disputes with her husband. He is a Lutheran Protestant turned Agnostic and rejects any form of fasting as an outdated form of religious practice. Having a chronic disease, fasting is not obligatory for Hayat, and she thus does not feel obliged to fulfill all the normative requirements. Still, she rejects her husband's demands that she should not fast at all.

Hayat: "He especially doesn't like to eat alone and tells me I am too sick to fast. Other people tell me so, too. [...] But when I feel well enough, I do the fasting."

Agency and choice are recurrent aspects in her narration. Given that, Hayat appreciates the apparent independence of the Burhaniyyah tariqa in Germany. 
Hayat: "There is more freedom because the mawlana [Shaykh] is in Sudan. He has murshids [engl. teacher, spiritual guide] in Germany, but because he himself does not visit that often, community life can develop more independently."

Due her disability, walking long distances is difficult, therefore she needs to have an infrastructure that allows accessibility when visiting the mosque. Hayat states that the Covid19 pandemic brought the advantage that meetings including the hadras and zikrs are being broadcasted online and are thus more accessible to her.

Ramadan is an important festivity to invite friends and family members for breaking the fast (arab. iftar). Selma has a son with her first husband, from whom she lives separated. She and her son lived some time alone and therefore developed some personal traditions surrounding Ramadan.

Selma: "So families invite each other, but I lived alone with Yünüs [son] for a few years, I did it in such a way that I invite all my girlfriends [...] when we still lived in the apartment. Yünüs was also befriended with their sons, so he invited his friends and I invited my girlfriends, on the same evening."

The adaption of cultural habits surrounding religious festivities according to one's personal situatedness, in this case as a separated Muslim mother, exemplifies how this situatedness, or positionality, influences practices. An approach by individuals to question or adapt norms that generate social expectations to their life reality is to mobilize resources (here the social resource 'friendship').

\subsection{Questioning, Adapting, Discarding Theological and Social Norms}

Miral describes how a year abroad and the years to follow made her question a lot more about the religious norms and rules she had grown up with. As mentioned above, she developed feelings of remorse and a severe identity crisis because of discrepancies between what felt genuine to her and what she had been taught as a child.

Miral: "My father has tried to enforce the principles, in which he was raised on [...] we had to pray regularly [...] My mom just read to me the beautiful suras that made her feel safe and belonging. [...] I admit, my father's approach made me turn away. So, at some point, I no longer wanted to pray."

The process of engaging in, questioning, turning away from and/or reconceptualizing and reconnecting to religious practices is rooted in social context. The latter can be the source of these practices, like family dynamics or communities, but can also be related to experiences which are made "elsewhere" in physical and discursive spaces. When Miral talks about her year abroad, the process of questioning had already started and was facilitated by this "elsewhere" that was not just set in a different locality but also offered connections for reconceptualization.

Mahnoush and Ramón used the Shi'i concept of temporary marriage (arab. mut'a, pers. sigheh) to give their relationship a religious framework which was important for Mahnoush. She decided that she needed this setting, when it became clear, that their relationship was serious. At first, it was a 'contract' solely between her partner and her, without that her parents were informed about it and without calling a Shaykh to authorize their decision. One should avoid an essentialist reading of temporary marriage, as for her, it worked in a manner that allowed for religious agency as they adapted the institution of mut'a according to their needs.

Mahnoush: "Actually, right at the beginning we concluded a temporary marriage solely between us. My parents were just recently informed about it. [This time] we invited a Shaykh to our place and had a video call with my parents. [...] It was a mere formality really, because we know, it's a serious relationship."

The respondent Nazira motivated her husband to organize more activities together surrounding Lent in their parish, besides the common Eastern worship services. According to her, the importance of community during Lent was not as essential compared to the 
Ashura festivities in her former Muslim community. She translated social traditions and practices she knew from her childhood into the Christian setting, like meeting early in the morning for prayer and sharing meals afterwards.

In Nazira's country of origin, civil marriage does not exist and both partners need to have the same religion because interreligious marriages are not carried out by any religious authorities. While conversion is an option for all genders, the expectation that a woman converts to her future husband's religion is a common societal expectation. Nazira holds the opinion that Islamic law, which consists of interpretation of Islamic sources and traditions, should be the center point of reformation. 'Reformation' means for her to become gender equal in the implementation of Islamic legal regulations.

Nazira: "According to the shari'a, or an interpretation of the shari'a, I wasn't a Muslim anymore, because the woman converts to the husband's belief. This doesn't have anything to do with Islam. This is patriarchal. [...] There are always

European voices who call for a reformation in Islam. But you cannot reform the Qur'an. You can only reform the shari'a"

Hayat's religious practices include the five Islamic ritual prayers without always abiding by the provided times. She has a spot dedicated for prayer in her flat and prays the al-Fatiha in Arabic, while she prays the other parts in German. A Muslim friend once asked her whether she is not afraid that consequently her prayers become invalid. She answered that every prayer prayed with an honest heart regardless of the language should count. In her opinion, the only kind of prayer that is invalid is one that is insincere.

Hayat: "When I pray in German, it feels different. I feel more present and deeply immersed in prayer."

Hayat's account on the feeling of being immersed in prayer exemplifies how the materiality and embodiment of religious practices relate to and negotiate with normativities. She explained to me, that praying the ritual prayer in another language than Arabic is enough of a taboo that she prefers not to be open about it to many of her Muslim friends.

\section{Discussion}

This paper traced the conceptualizations of religious identity and practices of intermarried/inter-partnered Muslim women. This included their concepts of being Muslim as well as challenges they encounter and the questioning and adaptations of authoritative concepts. This was done by showing interview excerpts dealing with spirituality and religion, challenges by social expectations and authoritative narratives and the inquiry of theological and social norms.

The situational approach taken in Situational Analysis helps to comprehend the positionality of interviewees as actors in a social field and to shed light on different practices that are associated, reproduced, adapted or changed within this positionality.

It is worth to further analyze how Muslim women's practices in interfaith couples are shaped by other forms of belonging such as class, ethnicity, nationality or sexual identity using situational mapping. This can clarify aspects of hegemonic subject positions in the framework of a European secular context, which influences how narratives of religious practices and identities are constructed within the respective frame of references.

Preliminary results illustrate that some respondents would appreciate a Muslim community that accepts their positionality as intermarried Muslim women. Concerning interfaith marriages, Islamic law establishes categories and functions as a hegemon. The majority opinion is based on presuppositional interpretations of the Islamic authoritative sources Qur'an and Sunna and on ideas about the social relationship between men and women. Rejected by most Muslim legal scholars to this day through both theological and social arguments, interfaith marriage for Muslim women remains a sensitive subject. Instead of drawing broad conclusions based on the empirical data, the purpose of this paper was to explore the research field of intermarried Muslims with a gender specific lens on embodiment and the interconnection of practices and norms. Thus, looking at the 
narration of religious practices and concepts of Muslimness in the interviews, it becomes clear that a classification as haram, or legally forbidden, puts a simple categorical bar in front of a socially and theologically complex context. Thereby, norms are perpetuated whose preconditions should rather be questioned.

Funding: This research received no external funding.

Informed Consent Statement: Informed consent was obtained from all subjects involved in the study.

Data Availability Statement: The data are not publicly available due to data confidentiality guaranteed to the subjects of the study.

Conflicts of Interest: The author declares no conflict of interest.

\section{References}

\section{Primary Sources}

Interview Mariam and Sebastian, 14 December 2019.

Interview Selma and Konstantin, 18 January 2020.

Interview Nazira, 25 February 2020.

Interview Hayat, 17 April 2020.

Interview Mahnoush and Ramón, 10 December 2020.

Interview Miral and Jonah, 2 March 2021.

Interview Enisa and Silvia, 7 July 2021.

Interview Shaykh Ibrahim Mogra (Embedded Video), Al-Jazeera, 31 December 2012. Minutes 1:08-1:28. Available online: https: //www.aljazeera.com/features/2012/12/31/halal-interfaith-unions-rise-among-uk-women (accessed on 8 October 2021).

Interview with Taj Hargey, Al-Jazeera, Last Modified 29 December 2012. Available online: https://www.youtube.com/watch?v= 7HBknbHp3R4 (accessed on 8 October 2021).

\section{Published Sources}

Abdelnour, Mohammad Gamal. 2020. Interreligious Relations: The Islamic Theology of Interfaith Marriages Between Theology, Law and Individual Ijtihad. Studies in Interreligious Dialogue 17: 59-71. [CrossRef]

Akca, Ayşe Almıla, Eyad Abuali, and Aydın Süer. Forthcoming. Bodies, Things, Doings. A Practice Theory Approach to the Study of Islam. In New Methods in the Study of Islam. Edited by Abbas Aghdassi and Aaron Hughes. Edinburgh: Edinburgh University Press.

Ali, Kecia. 2006. Sexual Ethics and Islam-Feminist Reflections on Qur'an, Hadith, and Jurisprudence. Oxford: Oneworld Publication.

Barlas, Asma. 2002. Believing Women in Islam: Unreading Patriarchal Interpretations of the Qur'an. Austin: University of Texas Press.

Bourdieu, Pierre. 1976. Entwurf einer Theorie der Praxis auf der Ethnologischen Grundlage der Kabylischen Gesellschaft. Frankfurt a. M.: Suhrkamp.

Buisson, Johanna Marie. 2016. Interfaith Marriages for Muslim Women. CrossCurrents 66: 430-49. [CrossRef]

Clarke, Adele, Carrie Friese, and Rachel Washburn, eds. 2015. Situational Analysis in Practice. Mapping Research with Grounded Theory. Walnut Creek: Left Coast Press.

Clarke, Adele. 2005. Situational Analysis_Grounded Theory after the Postmodern Turn. Thousand Oaks: Sage Publications.

Elmali-Karakaya, Ayse. 2021. Being Married to a Non-Muslim Husband: Religious Identity in Muslim Women's Interfaith Marriage. In Research in the Social Scientific Study of Religion: A Diversity of Paradigms. Edited by Ralph W. Hood and Sariya CheruvallilContractor. Leiden and Boston: Brill, pp. 388-410. [CrossRef]

Flick, Uwe, Ernst von Kardorff, and Ines Steinke, eds. 2017. Qualitative Forschung. Ein Handbuch. Reinbek: Rowohlt Verlag. First published 2005.

Fröhlich, Alexander, Jörn Hasselmann, and Hannes Heine. 2019. “Gebet im Freien” auf dem Tempelhofer Feld. Veranstalter-Verein soll Islamisten nahestehen. Der Tagesspiegel. August 11. Available online: https:/ / www.tagesspiegel.de/berlin/gebet-im-freien-aufdem-tempelhofer-feld-veranstalter-verein-soll-islamisten-nahestehen/24892200.html (accessed on 13 December 2021).

‘Halal' Interfaith Unions Rise Among UK Women. 2012. Aljazeera. December 31. Available online: https://www.aljazeera.com/ features /2012/12/31/halal-interfaith-unions-rise-among-uk-women (accessed on 13 November 2021).

Hillebrandt, Frank. 2014. Soziologische Praxistheorien-Eine Einführung. Wiesbaden: Springer VS.

Jawad, Haifaa, and Ayse Elmali-Karakaya. 2020. Interfaith Marriages in Islam from a Woman's Perspective: Turkish Women's Interfaith Marriage Practices in the United Kingdom. Journal of Muslim Minority Affairs 40: 1-20. [CrossRef]

Lamrabet, Asma. 2016. Women in the Qur'an. An Emancipatory Reading. Translated by Myriam Francois-Cerrah. Lancastershire: Kube Publishing/Square View.

Löw, Martina. 2001. Raumsoziologie. Frankfurt am Main: Suhrkamp Verlag. 
Menz, Margarete. 2008. Biographische Wechselwirkungen: Genderkonstruktionen und "Kulturelle Differenz" in den Lebensentwürfen Binationaler Paare. (Gender Studies). Bielefeld: Transcript Verlag. [CrossRef]

Przyborski, Aglaja, and Monika Wohlrab-Sahr. 2014. Qualitative Sozialforschung. Ein Arbeitsbuch. München: Oldenbourg Verlag.

Reckwitz, Andreas. 2002. The Status of the Material in Theories of Culture: From Social Structure to Artefacts. Journal for the Theory of Social Behaviour 32: 195-217. [CrossRef]

Reckwitz, Andreas. 2003. Grundelemente einer Theorie sozialer Praktiken. Zeitschrift für Soziologie 32: 282-301. [CrossRef]

Shove, Elizabeth. 2010. Social Theory and Climate Change. Theory, Culture E Society 27: 277-88. [CrossRef]

Strauss, Anselm, and Juliet Corbin. 1998. Basics of Qualitative Research: Techniques and Procedures for Developing Grounded Theory. Thousand Oaks, London: Sage Publications. First published 1996.

Strauss, Anselm. 2003. Qualitative Analysis for Social Scientists. Cambridge: Cambridge University Press. First published 1987.

Strübig, Jörg. 2008. Grounded Theory. Zur Sozialtheoretischen und Epistemologischen Fundierung des Verfahrens einer Empirisch Begründeten Theoriebildung. Wiesbaden: VS Verlag für Sozialwissenschaften.

Wadud, Amina. 1999. Qur'an and Women-Rereading the Sacred Text from a Woman's Perspective. Oxford: Oxford University Press.

When Two Faiths Meet-Marriage, Family and Pastoral Care: Ethical Principles. 2015. Christian Muslim Forum. December. Available online: https://www.dtppp.com/wp-content/uploads/2015/12/When-Two-Faiths-Meet-guidelines.pdf (accessed on 8 October 2021). 